\title{
Ontogeny and implication of pregnancy-associated agglutinin of the rat uterus*
}

\author{
P. K. Mukhopadhyay and M. Chowdhury \\ Indian Institute of Chemical Biology, 4, Raja S. C. Mullick Road, Calcutta 700032, India
}

\begin{abstract}
Summary. The mannose/fructose-binding agglutinin from Day 1-7 post coitum (p.c.) rat uteri was purified on Concanavalin $\mathrm{A}$. The specific haemagglutination activity peaked on Days 4 and 5 p.c. and a 1.4-fold increase in the yield was accompanied by a 10-12-fold increase in specific agglutination titre. The mannose-binding affinity of the protein also increased, but the highest fructose-binding affinity was found on Day 1 p.c., which may indicate a role of the protein in fructose concentration for utilization by the spermatozoa. Rats that were pseudopregnant, superovulated and pseudopregnant, and had one uterine horn ligated showed that, although a basal level of the protein was induced by the hormonal milieu, actual stimulation of the protein synthesis occurred in the presence of the fertilized ova.
\end{abstract}

Keywords: agglutinin; affinity chromatography; rat; uterus; pregnancy; blastocyst

\section{Introduction}

In the rat, implantation of the embryo is initiated on the 5th day of pregnancy (Psychoyos, 1973). The process requires a co-ordinated interaction between the embryo and a properly receptive uterus and uterine milieu. The protein composition of tubal and uterine fluids (Surani, 1975, 1977a, b; Shalgi et al., 1977; Takata \& Terayama, 1979) and the endometrium (Mulholland \& Villee, 1984) has been investigated to determine their possible roles in the series of reactions occurring during implantation. These investigators have provided clear evidence of synthesis and secretion of specific proteins which produce a specialized environment for fertilization, embryo development and implantation, while some other proteins found in the uteri of regularly cyclic rats are not being synthesized (Mulholland \& Villee, 1984).

The hormonal events that prepare the uterine environment for implantation have been reviewed (Mayer, 1963; Marcus \& Shelesnyak, 1970). The mechanisms whereby steroid hormones influence the blastocyst, the endometrium and other uterine tissues during gestation are poorly understood, but the overall effect results in initiation of synthesis of a spectrum of new proteins. Studies on uterine luminal proteins of mice during early pregnancy after superovulation (Fishel, 1980) revealed enhanced synthesis on Day 4 post coitum (p.c.).

The presence of one such new protein was observed on Day 4 p.c. in the rat uterus. This protein, being glycoprotein in nature, was purified by affinity chromatography with Concanavalin A-Sepharose and was called agglutinin because of its sugar-binding property (Chowdhury, 1986). This study presents the ontogeny of this Con A-purified agglutinin and focusses on the possible mechanism behind the enhanced synthesis around the time of implantation.

*Reprint requests to Dr M. Chowdhury. 


\section{Materials and Methods}

\section{Experimental animals and treatments}

Swiss albino virgin female rats $(150-200 \mathrm{~g})$ were obtained from the animal facility of our Institute. They were maintained under standard conditions, given food and water ad libitum and exposed to a lighting schedule of 05:00-19:00 h. Vaginal smears were taken every morning and animals having 3 consecutive 4-day oestrous cycles were used for the experiments. The following experimental groups were used.

Group I (normal pregnancy). Normal cyclic females at the pro-oestrous stage were caged with a proven fertile male. The day of a sperm-positive vaginal smear was considered as Day 1 of pregnancy instead of Day 0 as described earlier (Chowdhury, 1986). Animals were killed on Days 1-7 p.c.

Group II (pseudopregnancy-induced). Pseudopregnancy was induced in regular cyclic virgin females by cervical tapping. As described by DeFeo (1963), the cervices of animals at oestrus were tapped with a glass rod (2-3 mm diameter) for $\sim 2 \mathrm{~min}$ at a rate of $120 \mathrm{taps} / \mathrm{min}$. Day 1 of pseudopregnancy was characterized by the appearance of leucocytes in the smear. The animals were killed on Day 4 of pseudopregnancy.

Group III (pregnancy and pseudopregnancy after superovulation). Virgin females were superovulated by intraperitoneal injection of 5 i.u. PMSG (NIAMDD, Bethesda, MD, USA) on the evening of oestrus followed by 5 i.u. hCG (Pharmedical, Melrose Park, IL, USA) $48 \mathrm{~h}$ after the first injection. These superovulated animals were made pseudopregnant or pregnant by the methods described for Groups I and II. The animals were killed on Day 4 of pseudopregnancy or Day 4 p.c.

Group IV (unilateral tying of uterus). To study the effect of descending embryos on the production of the uterine protein, each animal was laparotomized between 16:00 and 18:00 h on Day 1 of pregnancy under light ether anaesthesia. One uterine horn was tied at the uterotubal junction with Ethicon silk thread 6-0 (Ethicon Inc., Summerville, NJ, USA) to prevent descent of the fertilized ova. The other horn served as the control. The animals were killed at Days 4 or 6 of pregnancy.

In all the experimental groups, the animals were killed under ether anaesthesia and uteri were removed, freed of surrounding fats, weighed and homogenized in $0.02 \mathrm{M}$-Tris- $\mathrm{HCl}$ buffer containing $0.15 \mathrm{M}-\mathrm{NaCl}$ and $0.001 \% \mathrm{NaN}_{3}$ (Tris buffer), $\mathrm{pH} 7.8(100 \mathrm{mg}$ tissue $/ \mathrm{ml})$. The uterine homogenates were centrifuged at $3000 \mathrm{~g}$ at $4^{\circ} \mathrm{C}$. The supernatants were kept at $-40^{\circ} \mathrm{C}$ for further purification.

The clear $3000 \mathrm{~g}$ supernatant was passed through a Con A-Sepharose 4B (Pharmacia Fine Chem., Uppsala, Sweden) column equilibrated with Tris buffer at $4^{\circ} \mathrm{C}$. After washing, the bound material was eluted at room temperature by $40 \mathrm{~mm}-\alpha$-methyl glucoside in Tris buffer. The effluents and eluants were monitored at $280 \mathrm{~nm}$. The eluted protein peak was dialysed and concentrated under vacuum.

To maintain standard conditions, equal amounts (mg crude protein) of uterine supernatants were loaded in the different affinity columns having the same bed volume and the yield was compared. Samples from each group were treated alike. The yield was calculated by dividing the total amount of purified protein $(\mu \mathrm{g})$ by the initial amount of crude protein $(\mathrm{mg})$ loaded to the column.

\section{Protein determination}

Protein concentration was determined by the method of Lowry et al. (1951) using crystalline bovine serum albumin (Sigma Chemical Co., St Louis, MO, USA) as the standard.

\section{Haemagglutination}

Haemagglutination tests (Chowdhury, 1986) were performed by the serial dilution technique in a Takatsy microtitrator (Laxbro Mfg Co., Bombay, India) with $25 \mu \mathrm{l}$ loops and $25 \mu \mathrm{l}$ of a $2 \%(\mathrm{v} / \mathrm{v}$ ) rabbit erythrocyte suspension in saline. Haemagglutination titre was determined $1 \mathrm{~h}$ after incubation at $25^{\circ} \mathrm{C}$. The reciprocal of the highest dilution of the agglutinin that produced visible agglutination was taken as the titre (units) and the specific activity was defined as total units/total proteins $(\mathrm{mg})$.

\section{Inhibition of haemagglutination}

The inhibition of haemagglutination by various inhibitors was studied as described previously (Chowdhury, [986). In brief, aliquants of sugar solutions $(25 \mu$ l) were serially diluted with $25 \mu$ l saline $(0.9 \% \mathrm{NaCl})$ in microtitre trays. A constant amount of $25 \mu \mathrm{l}$ agglutinin containing minimum haemagglutination units was added to each well. After incubation for $15 \mathrm{~min}, 25 \mu \mathrm{l}$ of a $2 \%(\mathrm{v} / \mathrm{v})$ rabbit erythrocyte suspension were added and the wells were examined after $1 \mathrm{~h}$. Results were expressed as the minimum concentrations (mM) of sugars required to inhibit $50 \%$ haemagglutination. 


\section{Results}

Agglutination profile in the developing pregnancy uteri

The affinity-purified proteins isolated from uteri of 3 animals killed at each day post coitum were pooled and concentrated before testing for their haemagglutination titre and yield. Data presented in Table 1 are the mean of two sets of experiments. Both the yield and the specific activity (Table 1) peaked around Days 4 and 5 followed by a sharp fall in activity. Sugar inhibition data presented here showed a variation in inhibition patterns. A lower concentration of mannose was needed to inhibit agglutination on Days 1, 4 and 5. The fructose inhibition pattern showed a gradual increase of sugar concentration needed for inhibition. The lowest value was found for Day 1.

Table 1. Developmental pattern of Con A-purified agglutinin of pregnant rat uterus (Group I)

\begin{tabular}{|c|c|c|c|c|c|}
\hline \multirow{2}{*}{$\begin{array}{l}\text { Day* } \\
\text { p.c. }\end{array}$} & \multirow{2}{*}{$\begin{array}{l}\text { Agglutination } \\
\text { titre/ml }\end{array}$} & \multirow{2}{*}{$\begin{array}{l}\text { Specific activity } \\
\text { (titre } / \text { mg protein) } \\
\times 10^{4}\end{array}$} & \multirow{2}{*}{$\begin{array}{c}\text { Yield } \\
(\mu \mathrm{g} / \mathrm{mg} \text { crude })\end{array}$} & \multicolumn{2}{|c|}{$\begin{array}{c}\text { Minimum concentration (mM) } \\
\text { of sugar required for } \\
50 \% \text { inhibition }\end{array}$} \\
\hline & & & & Mannose & Fructose \\
\hline 1 & 320 & 1 & $14 \cdot 4$ & $3 \cdot 46$ & $13 \cdot 8$ \\
\hline 2 & 320 & $1 \cdot 4$ & 15 & $6 \cdot 93$ & $27 \cdot 7$ \\
\hline 3 & 640 & $2 \cdot 7$ & 13.8 & 6.93 & $27 \cdot 7$ \\
\hline 4 & 5120 & $10 \cdot 2$ & 19.9 & $3 \cdot 12$ & 25 \\
\hline 5 & 5120 & $9 \cdot 3$ & $19 \cdot 3$ & $3 \cdot 46$ & $27 \cdot 7$ \\
\hline 6 & 640 & $2 \cdot 1$ & $14 \cdot 5$ & $6 \cdot 93$ & $55 \cdot 5$ \\
\hline 7 & 1280 & $2 \cdot 3$ & $15 \cdot 2$ & $6 \cdot 93$ & $55 \cdot 5$ \\
\hline
\end{tabular}

* Results presented are means of two sets of experiments.

\section{Effect of hormonal milieu on the agglutinin activity}

The specific activity and yield of agglutinin isolated from uteri of Day 4 pseudopregnant and normal Day 4 p.c. rats were compared. A significant $(P<0.05)$ increase in specific activity was noted in Day 4 p.c. uteri $(12 \cdot 8 \pm 0.95)$ compared to pseudopregnant samples $(1.6 \pm 0.05)$. The yield also showed a similar trend (pregnant $19 \cdot 2 \pm 0.2$ vs pseudopregnant $14.3 \pm 0.4,(P<0.05)$.

\section{Effect of induction of superovulation on agglutinin activity}

The same trend was observed in superovulated Day 4 p.c. and pseudopregnant animals. Both the specific activity (15.0 \pm 0.53 , Day 4 p.c., vs $0.97 \pm 0.24$, pseudopregnant) and the yield $(29.5 \pm 1.5$, Day 4 p.c., vs $9.5 \pm 3.4$, pseudopregnant $)$ were significantly $(P<0.05)$ higher in the Day 4 p.c. group.

\section{Effect of fertilized ova on the production of agglutinin}

In this group untied and tied horns from animals were pooled and the data presented are means of 2 experiments. As shown in Table 2, prevention of the downward movement of fertilized ova by tying affected both yield and specific activity of the agglutinin. Both values decreased considerably compared to those in the unligated uterine horn and the effect was more intense on Day 4 than on Day 6. 
Table 2. Effect of fertilized ova on uterine agglutinin production (Group IV)

\begin{tabular}{lcccc}
\hline & & \multicolumn{3}{c}{ Purified agglutinin } \\
\cline { 3 - 5 } Uterine & $\begin{array}{c}\text { Day* } \\
p . c .\end{array}$ & $\begin{array}{c}\text { Total } \\
\text { agglutination } \\
\text { titre }\end{array}$ & $\begin{array}{c}\text { Specific } \\
\text { activity } \\
\times 10^{4}\end{array}$ & Yield \\
\hline horn & 4 & 1024 & $1 \cdot 1$ & $17 \cdot 2$ \\
Tied & 4 & 14080 & 16 & $25 \cdot 8$ \\
Untied & 4 & 712 & $1 \cdot 4$ & $15 \cdot 2$ \\
Tied & 6 & 2944 & $4 \cdot 2$ & $20 \cdot 9$ \\
Untied & 6 & &
\end{tabular}

${ }^{*}$ Results are means of two sets of experiments.

\section{Discussion}

The results presented in this study illustrate the synthesis profile of the agglutinin isolated from Day 1-7 p.c. rat uteri (Table 1). Increased yield, reflecting increased synthesis, was observed on Day 4-5 p.c. but subsequently decreased. Generally, during and before implantation, an overall increase in RNA and protein synthesis of the uterus has been noted (O'Grady \& Bell, 1977). The developmental profile of this protein indicates that a 1.4-fold increase in total yield is accompanied by an approximately 10-fold increase in specific activity of agglutinin. This may signify that the sugar-binding affinity of the protein also increases during this period. The results illustrating the sugar inhibition profile (Table 1) confirm this assumption as half the concentration of mannose is needed for specific inhibition of Day 4-5 protein compared to other days. Only one interesting deviation observed was that, despite the fact that on Day 1 p.c. both yield and specific activity of agglutinin is low, it has the same binding affinity as Day 4-5 protein for mannose and highest binding affinity in the whole group for fructose. Taking into account that spermatozoa are present in the Day 1 p.c. uteri and they utilize hexoses (fructose, mannose, glucose) for their energy provision (Paterson \& Freund, 1969), it may be assumed that the agglutinin of Day 1, with its low concentration and high affinity for sugar, concentrates the sugar, especially fructose, for utilization by the spermatozoa. Such a change in the binding affinity may be caused by alteration in the secondary structure of the protein.

Normally fertilized rat ova take about 3 days to pass through the oviduct and on Day 4 p.c. they enter the uterus where they remain unattached until the early hours of Day 5 (Dickmann \& DeFeo, 1967). During this period the blastocysts may exert some uterotrophic action on uteri and stimulate protein synthesis (Nilsson, 1974). Since the period of blastocyst entry into the uterus has coincided with increased agglutinin synthesis, we have studied sequentially whether blastocysts stimulate the production of this substance.

The experiments were executed in a stepwise fashion. Firstly, the effect of the hormonal milieu on agglutinin production was studied using pseudopregnant animals. The result presented suggest that, although a background agglutinin activity was found in these animals, it was considerably lower than in the Day 4 p.c. controls. However, a significant increase $(P<0.05)$ in both specific activity and yield was observed in the experimental group when the animals were superovulated before making them pregnant or pseudopregnant. When the pregnant controls of 2 experiments were compared, it was noted that, despite the increase in agglutinin yield in superovulated animals, the specific activity remained the same, which suggests that superovulation possibly causes quantitative but not qualitative change in agglutinin production due to presence of a larger number of fertilized ova.

These experiments suggest that an identical hormonal milieu present during pregnancy and pseudopregnancy can initiate the production of agglutinin at a lower level; however, the stimulus needed for increased synthesis is provided by the embryos entering the uterus. This finding was 
further supported by the data of experiments using surgically manipulated animals (Table 2), in which specific activity and yield of agglutinin were higher in the non-ligated uterine horn than in the ligated horn.

Since the synthesis of this protein rises during the preimplantation period, this may indicate its involvement in the implanation process. As reported earlier (Chowdhury, 1986) this protein has Con A-like sugar-binding specificity and since preimplantation embryos have Con A receptors on their surfaces (Sobel \& Nebel, 1978), this agglutinin may play a role in directing the embryo to its implantation site in the endometrium.

It has also been reported that Con A can induce histamine release from both mast cells (Bergstrand et al., 1982) and basophils (Magro \& Bennick, 1977). Since one of the earliest manifestations of implantation is an increase in stromal capillary permeability at the location of the blastocyst, caused by histamine release from mast cells (Shelesnyak, 1957), this Con A-like agglutinin may play a role in implantation by inducing histamine release.

We thank the Indian Council of Medical Research for awarding a Junior Fellowship to P.K.M.; and Dr S. Raiti, Director, National Hormone and Pituitary Program, USA, for providing hormones.

\section{References}

Bergstrand, H., Bjornsson, A., Frick, I.M., Lundquist, B., Pauwels, R. \& Bazin, H. (1982) Anti-IgE and Con Ainduced histamine release from mast cells of four rat strains: correlation with total serum IgE. Agents \& Actions 12, 612-618.

Chowdhury, M. (1986) Isolation of a keto sugar specific agglutinin from rat uterus. Biochem. Biophys. Res. Commun. 136, $116-121$.

DeFeo, V.J. (1963) Temporal aspect of uterine sensitivity in the pseudopregnant or pregnant rat. Endocrinology 72, 305-316.

Dickmann, Z. \& DeFeo, V. J. (1967) The rat blastocyst during normal pregnancy and during delayed implantation including an observation on the shedding of the zona pellucida. J. Reprod. Fert. 13, 3-9.

Fishel, S.B. (1980) Radiolabelled uterine proteins during early pregnancy and pseudopregnancy after unilateral ovariectomy and superovulation. $J$. Reprod. Fert. 59, 473-478.

Lowry, O.H., Rosebrough, N.J., Farr, A.L. \& Randall, R.J. (1951) Protein measurement with the Folinphenol reagent. J. biol. Chem. 193, 265-275.

Magro, A.M. \& Bennick, H. (1977) Concanavalin A induced histamine release from human basophils in vitro. Immunology 33, 51-58.

Marcus, G.J. \& Shelesnyak, M.C. (1970) Steroids in nidation. In Advances in Steroid Biochemistry and Pharmacology, Vol 2, pp. 373-438. Eds G. J. Marcus \& M. C. Shelesnyak. Academic Press, New York.

Mayer, G. (1963) Delayed nidation in rats: a method for exploring the mechanism of ovo-implantation. In Delayed Implantation, pp. 213-231. Ed. A. C. Enders. University of Chicago Press.

Mulholland, J. \& Villee, C. A., Jr (1984) Proteins synthesized by the rat endometrium during early pregnancy. J. Reprod. Fert. 72, 395-400.

Nilsson, O. (1974) The morphology of blastocyst implantation. J. Reprod. Fert. 39, 187-194.
O'Grady, J.E. \& Bell, S.C. (1977) The role of the endometrium in blastocyst implantation. In Development in Mammals, Vol I, pp. 165-243. Ed. M. H. Johnson. North Holland, Amsterdam.

Paterson, R.N. \& Freund, M. (1969) Glycolysis by washed suspension of human spermatozoa: effects of substrate, substrate concentration and changes in medium composition on the rate of glycolysis. Biol. Reprod. 1, 238-246.

Psychoyos, A. (1973) Hormonal control of ovoimplantation. Vitams Horm. 31, 201-256.

Shalgi, R., Kaplan, R. \& Kraicer, P.F. (1977) Proteins of follicular, bursal and ampullar fluids of rat. Biol. Reprod. 17, 333-338.

Shelesnyak, M.C. (1957) Some experimental studies on the mechanism of ova-implantation in the rat. Recent Prog. Horm. Res. 13, 269-322.

Sobel, J.S. \& Nebel, L. (1978) Changes in Concanavalin A agglutinability during development of the inner cell mass and trophoblast of mouse blastocysts in vitro. $J$. Reprod. Fert. 52, 239-248.

Surani, M.A.H. (1975) Hormonal regulation of proteins in the uterine secretion of ovariectomized rats and the implication for implantation and embryonic diapause. J. Reprod. Fert. 43, 411-417.

Surani, M.A.H. (1977a) Qualitative and quantitative examination of the proteins of rat uterine luminal fluid during proestrus and pregnancy and comparison with those of serum. J. Reprod. Fert. 50, 281-287.

Surani, M.A.H. (1977b) Radiolabelled rat uterine luminal proteins and their regulation of estradiol and progesterone. J. Reprod. Fert. 50, $289-296$.

Takata, K. \& Terayama, H. (1979) Estrogen-dependence and progesterone-arrested synthesis and secretion of sulphated glycoproteins in the luminal epithelia of rat uteri. Biochem. Biophys. Acta 586, 594-607.

Received 27 June 1988 